\title{
Statyba
}

\section{THE INFLUENCE OF TECHNOLOGICAL FACTORS ON FOAM-GASEOUS SILICATE FORMATION MIXTURES AND PRODUCT PROPERTIES}

\section{A. Laukaitis}

To cite this article: A. Laukaitis (1998) THE INFLUENCE OF TECHNOLOGICAL FACTORS ON FOAM-GASEOUS SILICATE FORMATION MIXTURES AND PRODUCT PROPERTIES, Statyba, 4:1, 49-55, DOI: $10.1080 / 13921525.1998 .10531379$

To link to this article: https://doi.org/10.1080/13921525.1998.10531379

Published online: 26 Jul 2012.

Submit your article to this journal $\llbracket$

Щ Article views: 40 


\section{TECHNOLOGINIŲ VEIKSNIŲ ITTAKA PUTŲ-DUJŲ SILIKATBETONIO FORMAVIMO MIŠINIŲ IR PRODUKTO SAVYBĖMS}

\section{A. Laukaitis}

\section{1. İvadas}

Akytasis betonas yra ekologiškai švari, efektyvi vietinè statybos medžiaga. Jo savybès priklauso ne tik nuo gaminių tankio, bet ir nuo jo rūšies [1]. 250-500 $\mathrm{kg} / \mathrm{m}^{3}$ tankio dujų silikatbetonio, dujų ir putų cementbetonio technologiniai gamybos veiksniai ir savybès yra ištirtos Termoizoliacijos instituto mokslininku [217]. Ju gamyba išplètota Lenkijoje, Čekijoje, Švedijoje, Rusijoje [18], Vokietijoje [19]. Tačiau putų-duju silikatbetonis yra mažai ištirtas. Žinoma, kad ịdejjus i smèlio šlamą arba ị dujų silikatbetonio mišini paviršių aktyvinančias medžiagas (PAM), maišant yra ịtraukiamas oras ir šlamas arba silikatbetonio mišinys yra porizuojamas.

Nurodoma [20], kad i̊dejjus ił $400 \mathrm{~kg} / \mathrm{m}^{3}$ tankio dujų cementbetonio mišini $50 \mathrm{~g}$ paviršiu aktyvinančios medžiagos - sulfanolio ir papildomai maišant ji skiedinio maišyklèje, mišinys papildomai porizuojamas ir galima sutaupyti iki $10 \%$ aliuminio miltelių. Pakilus mišinio temperatūrai nuo $20^{\circ} \mathrm{C}$ iki $70^{\circ} \mathrm{C}$, putụ stabilumas sumažeja 2,5-3,0 kartus [21], o maišant paviršių aktyvinančią medžiagą su dujų cementbetonio mišinio komponentais itraukto oro kiekis priklauso nuo $\mathrm{V} / \mathrm{K}$, paviršių aktyvinančios medžiagos rūšies bei skiedinio maišyklès apsisukimų skaičiaus.

Naudojant dalinę akytojo betono mišinio porizaciją paviršiu aktyvinančia medžiaga "Progres" $(0,2$ $0,3 \%$ kietuju medžiagu), dél smulkiu pory beautoklavio $300 \mathrm{~kg} / \mathrm{m}^{3}$ tankio akytojo betono stipris gniuždant padideja $15-20 \%$, o atsparumas šalčiui 1,5 - 2 kartus, lyginant su dujų cementbetoniu arba puty cementbetoniu [22].

Lyginamieji $280-300 \mathrm{~kg} / \mathrm{m}^{3}$ tankio ịv airių akytojo betono rūšiu techniniai rodikliai pateikti darbe [5], tačiau nenurodyti ju gamybos technologiniai parametrai.

Šio darbo tikslas yra ištirti $300 \mathrm{~kg} / \mathrm{m}^{3}$ tankio putu - duju silikatbetonio gamybos technologinius veiksnius ir savybes. Optimaliems minéto tankio gaminiu forma- vimo veiksniams nustatyti buvo ištirtas platesnis tankio intervalas.

\section{Tyrimu metodika}

Bandymams buvo naudojamas Vilniaus Paneriu telkinio kvarcinis smèlis, AB "Akmenès cementas" CEM 42,5 markès portlandcementis ir kalcitinès gabalinès kalkès. Cheminè žaliavu sudétis pateikta 1 lenteleje.

Smèlis buvo malamas rutuliniu malūnu šlapiuoju būdu nuo 130 iki $500 \mathrm{~m}^{2} / \mathrm{kg}$ savitojo paviršiaus. Gabalinès kalkès su smèlio priedu buvo malamos vibraciniu malūnu iki $540 \mathrm{~m}^{2} / \mathrm{kg}$ savitojo paviršiaus, maltu kalkiu aktyvumas - $71 \%$, gesinimosi trukmè 16 $20 \mathrm{~min}$, gesinimosi temperatūra $54^{\circ} \mathrm{C}$. Portlandcemenčio rišimosi pradžia - $2 \mathrm{~h}$, pabaiga $5 \mathrm{~h} 50 \mathrm{~min}$.

Smèlio šlamo ir akytojo silikatbetonio mišinio porizacija buvo atlikta laboratoriniu vertikaliu maišytuvu, kurio apsisukimai buvo $750 \mathrm{~min}^{-1}$. Buvo naudojamos paviršių aktyvinančios medžiagos sulfanolis ir OP-10 (etilfenilo etilenglikolio eteris). Papildomu dujodariu buvo aliuminio milteliai, hidrofilizuoti sulfanoliu $(20 \mathrm{~g} / \mathrm{kg})$. Formavimo mišiniu buvo užpiltos $340 \times 340 \times 400 \mathrm{~mm}$ formos. Bandiniy kietinimo ciklas autoklave $1,5+8+1,5 \mathrm{~h}$, sočiuju vandens gary slègis izoterminio išlaikymo metu - 0,79 MPa.

Putu-duju silikatbetonio gamybos technologiniai veiksniai: mišinio aktyvumas $-28 \%, \mathrm{~V} / \mathrm{K} 0,55-0,75$, aliuminio miltelių kiekis $0,25-0,4 \%$ kietujju medžiagų, paviršiu aktyvinančiu medžiagu kiekis $0,1-1,0 \%$ kietujjų medžiagų.

Formavimo mišinio plastiškajj stiprị nustateme pagal formulę:

$$
P_{p l}=\frac{M}{h^{2}} \cdot 1,5 .
$$

Čia $P_{p l}$ - plastiškasis stipris, $\mathrm{N} / \mathrm{mm}^{2} ; M$ - kūgio masè, $\mathrm{N} ; h$ - kūgio ịsmigimo gylis, $\mathrm{mm}$. 
1 lentelè. Žaliavų cheminè sudètis

Table 1. Raw material chemical composition

\begin{tabular}{|l|c|c|c|c|c|c|c|c|}
\hline \multirow{2}{*}{ Žaliavos } & \multicolumn{8}{|c|}{ Sudetis, \% } \\
\cline { 2 - 10 } & $\mathrm{SiO}_{2}$ & $\mathrm{Al}_{2} \mathrm{O}_{3}$ & $\mathrm{Fe}_{2} \mathrm{O}_{3}$ & $\mathrm{CaO}$ & $\mathrm{MgO}$ & $\mathrm{R}_{2} \mathrm{O}$ & $\mathrm{SO}_{3}$ & Kaitmenys \\
\hline Smelis & 89,77 & 4,55 & 0,63 & 3,10 & 0,25 & 0,44 & 0,46 & 1,35 \\
\hline Kalkès & 3,13 & 0,99 & 0,16 & 81,83 & 1,40 & 0,59 & 1,03 & 10,87 \\
\hline Portlandcementis & 21,41 & 6,76 & 4,86 & 59,33 & 2,47 & - & 1,70 & 1,74 \\
\hline
\end{tabular}

Formavimo mišinio konsistencija buvo vertinama Suttardo viskozimetru. Bandinių stipris gniuždant esant norimam stipriui buvo perskaičiuotas pagal formulę [10].

Formavimo mišinio aktyvumo pagal smèlio šlamo smulkumą bei paviršiu aktyvinančią medžiagą ịtaka bandinių stiprumui buvo nustatyta formuojant lietus silikatbetonio bandinius (be aliuminio milteliu), kurie buvo kietinami autoklave tuo pačiu režimu.

Lietụ bandinių stiprị gniuždant perskaičiavome $1100 \mathrm{~kg} / \mathrm{m}^{3}$ tankiui pagal formulę [6]

$$
R_{1100}=\frac{R_{\text {fakt }}}{9,13 \cdot 10^{-4} \rho_{\text {fakt }}-3,81 \cdot 10^{-3}} .
$$

Čia $R_{1100}-1100 \mathrm{~kg} / \mathrm{m}^{3}$ tankio silikatbetonio stipris gniuždant, MPa; $R_{\text {fakt }}$ - faktinio tankio silikatbetonio stipris gniuždant, MPa; $\rho_{\text {fakt }}$ - silikatbetonio faktinis tankis, $\mathrm{kg} / \mathrm{m}^{3}$.

Akytojo silikatbetonio porų, susidarančị įtraukiant orą, maišant silikatbetonio mišinio komponentus su paviršių aktyvinančia medžiaga ir išsiskiriant vandenilio dujoms aliuminio miltelių reakcijoje su kalkèmis, santykis buvo nustatytas pagal mišinio išsipūtimo aukštị atitinkamai minètiems procesams.

\section{Rezultatai ir jụ aptarimas}

Mažo tankio akytojo silikatbetonio bandinių stipris gniuždant priklauso ne tik nuo žaliavụ smulkumo, rišamosios medžiagos kiekio, bet ir nuo jo struktūros. Todel noredami išeliminuoti pastarosios poveiki ir nustatyti, kokiam smélio sumalimo smulkumui esant reikia parinkti optimalų mišinio aktyvumą, buvo formuojami lieti silikatbetonio bandiniai. Sudetis pateikta 2 lentelèje.

Liety̨ silikatbetonio bandinių stipris gniuždant priklauso nuo mišinio aktyvumo, kuris esant skirtingam malto smèlio smulkumui yra skirtingas (1 pav.). Naudojant silikatbetonio gamybai smulkiau maltą sméli, reikia didinti ir mišinio aktyvumą. Kai smèlio savitasis paviršius yra $130 \mathrm{~m}^{2} / \mathrm{kg}$, optimalus mišinio aktyvumas yra $20 \%, 340-27-28 \%$, o $500-31 \%$ (1 pav., 1-3 kreivès).

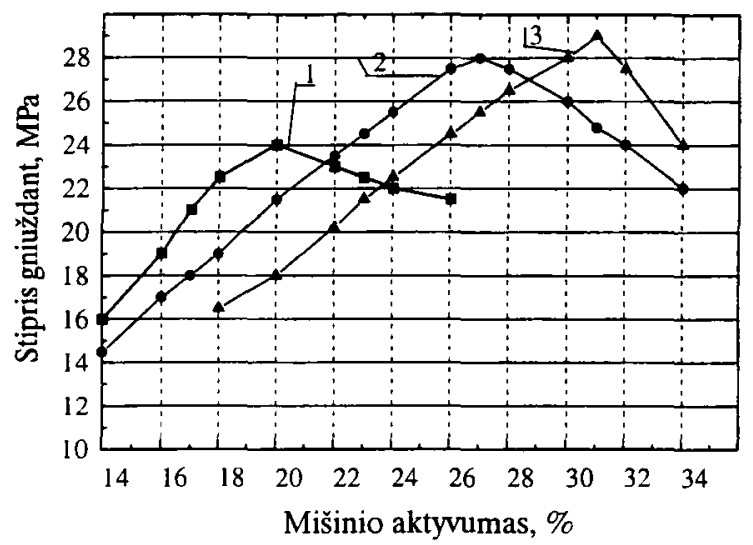

1 pav. Lietụ silikatbetonio bandiniu stiprio gniuždant priklausomybè nuo mišinio aktyvumo, kai malto smèlio smulkumas, $\mathrm{m}^{2} / \mathrm{kg}: 1$ - 130, 2 - 340, 3 - 500

Fig 1. Cast silicate concrete sample compression strength dependency on mixture activity, at milled sand fineness, $\mathrm{m}^{2} / \mathrm{kg}: 1$ - 130, 2 - 340, 3 - 500

Toliau didinant mišinio aktyvumą, bandiniu stipris gniuždant pradeda mažèti (esant rišamosios medžiagos pertekliui susidaro aukštesnio bazingumo kalcio hidrosilikatai, be to, mišinys perkaista). Apibendrinus pateiktus grafikus galima teigti, kad lengviems akytojo silikatbetonio gaminiams racionalu naudoti smèli, kurio savitasis paviršius bũtu $300-350 \mathrm{~m}^{2} / \mathrm{kg}$, o mišinio aktyvumas $26-28 \%$. Tolesni bandymai buvo atliekami su $340 \mathrm{~m}^{2} / \mathrm{kg}$ smulkumo smeliu ir esant $28 \%$ mišinio aktyvumui.

Ištyrus paviršių aktyvinančių medžiagu (PAM) poveikị lieto silikatbetonio bandinių stipriui gniuždant nustatyta, kad nedideli šių medžiagų kiekiai $(0,1$ $0,2 \%$ ) labai nedaug mažina bandiniu stiprị gniuždant (2 pav.). Idejus šiu priedų $0,5 \%$, OP -10 sumažina ši stiprị nuo 24 iki $21,5 \mathrm{MPa}$, t.y. $10,4 \%$, o sulfanolis nuo 24,0 iki $20 \mathrm{MPa}$, t.y. 16,66\% .

İtraukto oro kiekis maišant smèlio šlamą su paviršių aktyvinančia medžiaga priklauso nuo maišy- 
mo trukmès ( 3 pav.). Tačiau pagrindinis rezultatas pasiekiamas per $5 \mathrm{~min}$. Šlamo tankis naudojant sulfanoli sumažeja nuo $1,7 \mathrm{iki} 0,8 \mathrm{~kg} /$, t.y. $2,1 \mathrm{karto}$, o naudojant $\mathrm{OP}-10$ - nuo $1,7 \mathrm{iki} 0,93 \mathrm{~kg} /$, t.y. 1,83 karto. Tęsiant šlamo maišymą nuo 5 min iki $10 \mathrm{~min}$, smèlio šlamo tankis keičiasi nedaug ( 3 pav.). Jau po $2 \mathrm{~min}$ šlamo tankis pasikeičia nuo 1,7 iki $0,95 \mathrm{~kg} /$, t.y. 1,79 karto naudojant sulfanoli, ir nuo $1,7 \mathrm{iki} 1,1 \mathrm{~kg} /$, t.y. 1,54 karto naudojant OP-10.

Maišyti PAM su visais mišinio komponentais yra efektyviau negu atskirai išplakti šlamą su paviršiu aktyvinančia medžiaga, po to sudozuoti kalkes ir išmaišyti jas su jau išpūstu smèlio šlamu (4 pav.). Tai galima paaiškinti tuo, kad pilant kalkes i išpūstą smèlio šlamą jo poringa struktūra yra dalinai ardoma.

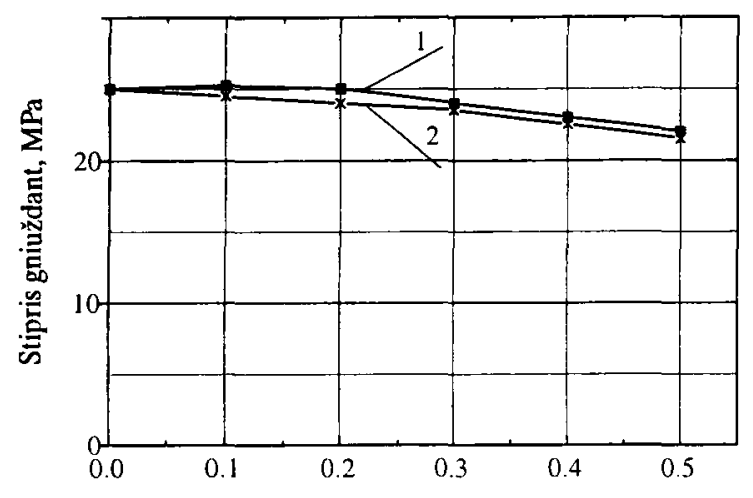

Paviršių aktyvinančios medžiagos kiekis, \%

2 pav. Paviršiu aktyvinančiu medžiagu kiekio ịtaka lieto silikatbetonio bandinių stipriui gniuždant: 1 - OP-10;2 sulfanolis

Fig 2. Surface active material amount influence on cast silicate concrete sample compression strength:1 - OP-10; 2 Sulphanol

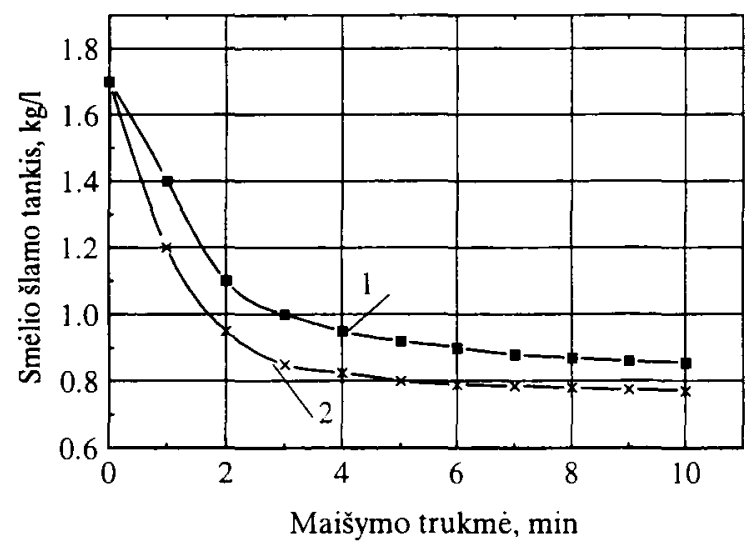

3 pav. Maišymo trukmès ịtaka smelio šlamo tankiui, kai paviršių aktyvinančios medžiagos: 1 - OP-10;2 - sulfanolis

Fig 3. The influence of mixing time on sand slime density with surface active materials: 1 - OP-10; 2 - Sulphanol

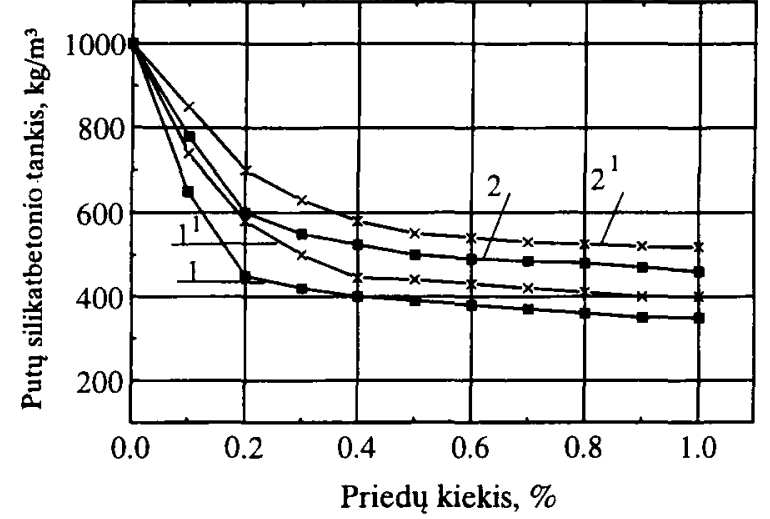

4 pav. Putu silikatbetonio tankio priklausomybè nuo paviršił aktyvinančios medžiagos kiekio ir maišymo būdo: 1 - sulfanolis; 2 - OP-10. 1, 2 - visi mišinio komponentai maišomi kartu; $1^{1}, 2^{1}$ smèlio šlamas maišomas su paviršiu aktyvinančia medžiaga, vèliau su kitais mišinio komponentais

Fig 4. Foam silicate concrete dependency on surface active materials amount and mixing method: 1 - Sulphanol; 2 - OP$10 ; 1,2$ - All the components mixed together; $1^{1}, 2^{1}$ - Sand slime mixed with surface active material and later with other solid mixture components

Paviršių aktyvinantieji priedai mažina putu silikatbetonio formavimo mišinio takumą, tačiau sulfanolis turi kur kas didesnès įtakos. Pvz., kai priedo kiekis $0,3 \%$, OP-10 sumažina mišinio takumą nuo $30,3 \mathrm{iki}$ $29,8 \mathrm{~cm}(1,65 \%)$, o sulfanolis nuo 30,3 iki $28,5 \mathrm{~cm}$ $(5,9 \%)$, kai priedo kiekis $0,5 \%$ - nuo 30,3 iki $29,5 \mathrm{~cm}$ $(2,64 \%)$ ir nuo 30,3 iki $25,7 \mathrm{~cm}(15,18 \%)$ atitinkamai (5 pav.).

Mišinio takumas sumažeja dèl įtraukto maišymo metu oro, todèl galima teigti, kad sulfanolis yra efektyvesnè paviršių aktyvinanti medžiaga negu OP-10.

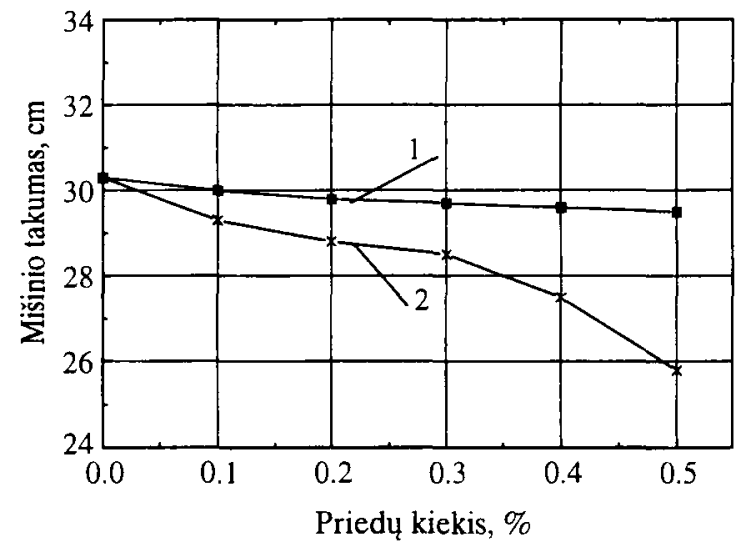

5 pav. Silikatbetonio mišinio $(\mathrm{V} / \mathrm{K}=0,6)$ takumo priklausomybè nuo paviršių aktyvinančių medžiagų kiekio: 1 - OP-10; 2 - sulfanolis

Fig 5. Foam silicate concrete mixture ( $\mathrm{V} / \mathrm{S}=0,6)$ plasticity dependency on surface active material amounts: 1 - OP-10; 2 - Sulphanol 
2 lentelè. Lietụ silikatbetonio mišinių technologiniai parametrai

Table 2. Cast silicate concrete mixture technological parameters

\begin{tabular}{|c|c|c|c|c|c|c|c|c|}
\hline \multirow{2}{*}{$\begin{array}{c}\text { Smelio } \\
\text { smulkumas, } \\
\mathrm{m}^{2} / \mathrm{kg}\end{array}$} & \multicolumn{7}{|c|}{ Mišinio aktyvumas } \\
\cline { 2 - 9 } & $14-17$ & $17-20$ & $20-23$ & $23-26$ & $26-29$ & $29-32$ & $32-34$ \\
\hline 130 & 0,52 & 0,54 & 0,54 & 0,56 & 0,56 & - & - \\
\hline 340 & 0,54 & 0,56 & 0,58 & 0,58 & 0,60 & 0,62 & 0,64 \\
\hline 500 & - & 0,56 & 0,58 & 0,60 & 0,62 & 0,64 & 0,66 \\
\hline
\end{tabular}

Maišant silikatbetonio mišini su PAM negalima pasiekti bandiniu tankio, mažesnio nei $400 \mathrm{~kg} / \mathrm{m}^{3}$. Todèl tolesni bandymai buvo atliekami maišant silikatbetonio mišinio komponentus su sulfanoliu ir papildomai pridedant aliuminio milteliu, t.y. buvo gaminamas putu-dujų silikatbetonis. Jo tankis analogiškai dujų silikatbetoniui taip pat priklauso nuo mišinio $\mathrm{V} / \mathrm{K}$ ir aliuminio milteliu kiekio (6 pav.)

$300 \mathrm{~kg} / \mathrm{m}^{3}$ tankio putų-dujų silikatbetonio gamybos technologiniai parametrai yra tokie: mišinio aktyvumas - $28 \%, \mathrm{~V} / \mathrm{K}-0,65$, sulfanolio kiekis - $0,1 \%$, aliuminio milteliu kiekis $0,4 \%$. Jo gamybos technologija tokia: sudozuoti mišinio komponentai 2 min maišomi su $0,1 \%$ sulfanolio, įdedama aliuminio miltelių suspensijos ir maišoma dar 1 min. Mišinys supilamas i

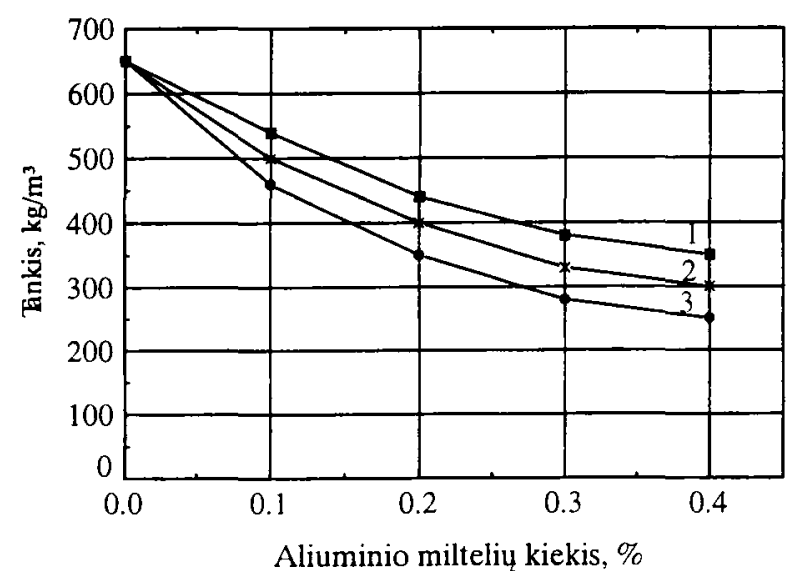

6 pav. Putų-dujų silikatbetonio tankio priklausomybè nuo aliuminio miltelių kiekio (mišinio komponentai 2 min maišyti su $0,1 \%$ sulfanolio), kai mišinio $\mathrm{V} / \mathrm{K}: 1$ - 0,6; 2 - 0,65; $3-0,7$

Fig 6. Foam-gaseous silicate concrete density dependency on aluminium powder amount (mixture components were mixed for $2 \mathrm{~min}$, with $0,1 \%$ Sulphanol), where mixture V/S ratio: 0,$6 ; 2-0,65 ; 3-0,7$ formą ir joje pučiasi del išsiskyrusio reakcijoje vandenilio.

Tiriant $300 \mathrm{~kg} / \mathrm{m}^{3}$ tankio akytojo silikatbetonio masès plastiškaji stiprị nustatyta, kad duju silikatbetonio masès plastiškasis stipris, lyginant ji su kitomis akytojo silikatbetonio rūšimis, yra didžiausias: po $2,5 \mathrm{~h}$ jo reikšmé yra $2,3210^{-3} \mathrm{~N} / \mathrm{mm}^{2}$ ( 7 pav., 5 kreivè), o putu silikatbetonio - mažiausias - po $3,5 \mathrm{~h}-0,84 \cdot 10^{-3}$ $\mathrm{N} / \mathrm{mm}^{2}$ ( 7 pav., 1 kreive). Putų-duju silikatbetonio masès plastiškasis stipris užima tarpinę padètį, jis dideja mažejjant poru, gautu maišant mišinio komponentus su PAM kiekiu. Pvz., kai 75\% porų, gaunama maišant mišinio komponentus su PAM, masès plastiškasis stipris po $150 \min$ buvo $2,2 \cdot 10^{-3} \mathrm{~N} / \mathrm{mm}^{2}$, t.y. padidejo 1,9 karto (7 pav., 2, 4 kreivès).

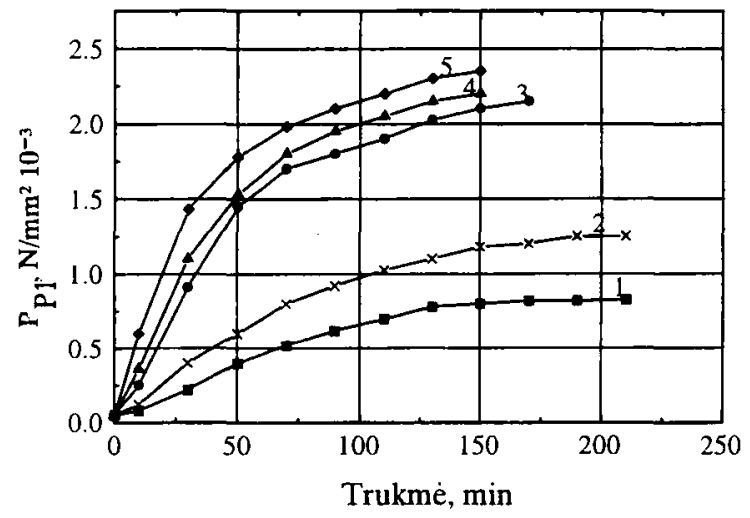

7 pav. $300 \mathrm{~kg} / \mathrm{m}^{3}$ tankio akytojo silikatbetonio masès plastiškojo stiprio priklausomybe nuo jo rūšies ir struktūros formavimo būdo: 1 - putu silikatbetonis (putos išplaktos atskirai), 2 - putų-duju silikatbetonis (25\% poru, gautu del $\mathrm{Al}$ milteliu $+75 \%$ porų, gautų maišant mišinio komponentus su PAM); 3 - putu-duju silikatbetonis $(50 \%+$ $50 \%) ; 4$ - putu-duju silikatbetomis $(75 \%+25 \%) ; 5$ - duju silikatbetonis (be PAM)

Fig 7. Porous silicate concrete $\left(300 \mathrm{~kg} / \mathrm{m}^{3}\right)$ mass plasticity strength dependency on its type and structure formation method: 1 - foam silicate concrete (foam made separately), 2 - Foam-gaseous silicate concrete ( $25 \%$ pores due to Al powder $+75 \%$ pores produced by mixing components with SAM), 3 - Foam-gaseous silicate concrete $(50 \%+50 \%)$, 4 - Foam-gaseous silicate concrete $(75 \%+25 \%)$,

5 - Gaseous silicate concrete (without SAM) 


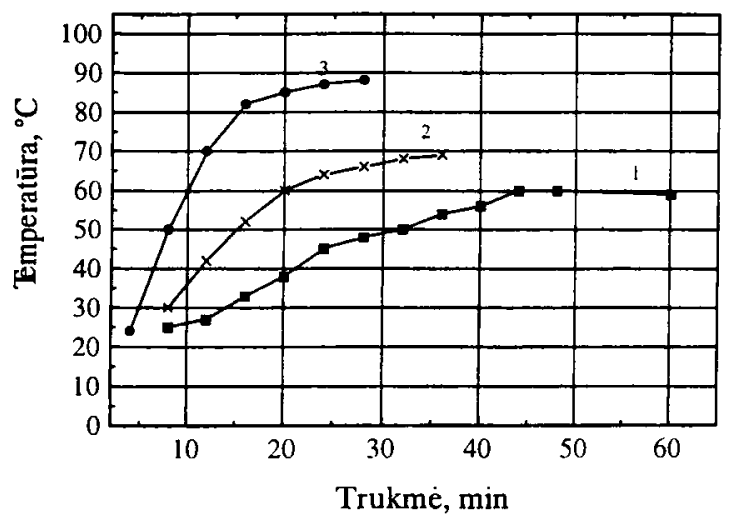

8 pav. Akytojo silikatbetonio mišinio temperatūros kitimas: 1 - putu silikatbetonis (putos išplaktos atskirai); 2 - putųdujų silikatbetonis $(50 \%$ poru, gautų dè $\mathrm{Al}$ miltelių $+50 \%$ porų, gautu maišant mišinio komponentus su PAM); 3 - duju silikatbetonis (be PAM)

Fig 8. Porous silicate concrete mixture temperature Alterations: 1 - Foam silicate concrete (foam made separately), 2 - Foam-gaseous silicate concrete $(50 \%$ pores due to $\mathrm{Al}$ powder $+50 \%$ produced by mixing mixture components with SAM), 3 - Gaseous silicate concrete (without SAM)

Akytojo silikatbetonio mišinio aukščiausia temperatūra priklauso nuo akytojo silikatbetonio rūšies. Dujų silikatbetonio mišinys jau po $30 \mathrm{~min}$ pasiekia $88^{\circ} \mathrm{C}$ temperatūrą ( 8 pav., 3 kreivè). Putų silikatbetobetonio temperatūra kyla lètai ir $60 \mathrm{~min}$ ji yra $60^{\circ} \mathrm{C}$ (8 pav., 1 kreive). Putų-duju silikatbetonio mišinio temperatūra užima tarpinę padètį. Po $36 \mathrm{~min}$ jis įšla iki $69^{\circ} \mathrm{C}$ ( 8 pav., 2 kreivè).

Bandinių stipris gniuždant yra didžiausias puty silikatbetonio, o mažiausias dujų silikatbetonio (9 pav). Putu-duju silikatbetonio bandinių stipris gniuždant užima tarpinę padetį ir tiesiogiai priklauso nuo porų, gauty plakant smélio šlamą su PAM ir maišant mišini su $\mathrm{Al}$ milteliais, santykio. Pvz., bandinių, kurių struktūroje $25 \%$ pory gaunama maišant mišinio komponentus su PAM ir $75 \%$ rišamosios medžiagos reakcijoje su Al milteliais, stipris gniuždant yra $0,9 \mathrm{MPa}$, tai šis porų santykis yra atvirkštinis - 1,1 $\mathrm{MPa}$, t.y. padidejja $22,22 \%$. Tai lemia del skirtingo porizacijos būdo bei skirtingo masès įsilimo laipsnio susidariusios porų struktūros forma, kas buvo ištirta ankstesniuose mūsų darbuose $[8,13,15]$. Akytojo betono struktūroje, susidarančioje esant masès temperatūrai $78-85^{\circ} \mathrm{C}$, vyrauja smulkios ir tolygiau pasiskirsčiusios taisyklingesnès formos poros, del to padideja ju mechaninis stiprumas. Pakilus masès aukščiausiai temperatūrai iki $95-100^{\circ} \mathrm{C}$, akytojo betono struktūra pablogeja, nes susidaro didesnio skersmens, tarpusavyje susisiekiančios, netaisyklingos formos poros, kas ir mažina bandinių stiprumą.

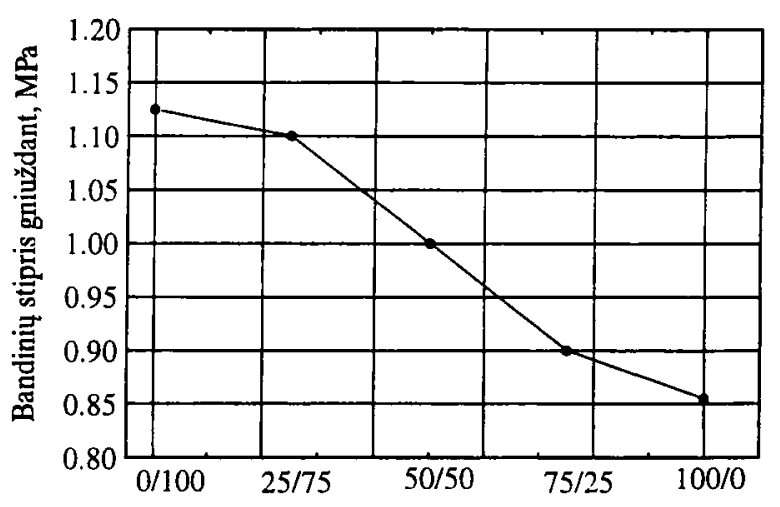

Porų santykis: maišant su $\mathrm{Al}$ milteliais / maišant su PAM, \%

9 pav. $300 \mathrm{~kg} / \mathrm{m}^{3}$ tankio akytojo silikatbetonio stiprio gniuždant priklausomybè nuo struktūros formavimo būdo (porų, gautų maišant mišinị su Al milteliais ir su PAM, santykio)

Fig 9. Porous silicate concrete $\left(300 \mathrm{~kg} / \mathrm{m}^{3}\right)$ compression strength dependency on structure formation method (pores produced by mixing the mixture with $\mathrm{Al}$ powder and with SAM, ratio)

\section{Išvados}

1. Formuojant lietus (be aliuminio mitelių) silikatbetonio bandinius nustatyta, kad mišinio aktyvumas turi būti parenkamas pagal malto smèlio smulkumą: kai jo savitasis paviršius $130 \mathrm{~m}^{2} / \mathrm{kg}$, mišinio aktyvumas turi būti $20 \%, 340 \mathrm{~m}^{2} / \mathrm{kg}-26-28 \%, 500$ $\mathrm{m}^{2} / \mathrm{kg}-31 \%$.

2. Silikatbetonio mišini galima iš dalies porizuoti maišant smèlio šlamą su paviršių aktyvinančia medžiaga (PAM), po to dozuoti kitus mišinio komponentus arba visus mišinio komponentus maišant su PAM. Antrasis būdas yra efektyvesnis, nes nesuardoma porizuota mišinio struktūra dozuojant kitus mišinio komponentus. Paviršių aktyvinančia medžiaga gerai tinka sulfanolis.

3. $300 \mathrm{~kg} / \mathrm{m}^{3}$ tankio putų-duju silikatbetonio technologiniai parametrai: mišinio aktyvumas $28 \%$, $\mathrm{V} / \mathrm{K}-0,65$, sulfanolio kiekis $0,1 \%$, aliuminio milteliu kiekis $0,4 \%$. Formavimo mišinio paruošimo technologija tokia: mišinio komponentai 2 min maišomi maišykleje $\left(750 \mathrm{~min}^{-1}\right)$ su sulfanoliu, ipilama aliuminio miltelių suspensijos ir maišoma dar 1 min. Paruoštas formavimo mišinys supilamas $i$ formas.

4. Putų-dujų silikatbetonio masès plastiškasis stipris užima tarpinę padetị tarp duju silikatbetonio ir puty silikatbetonio ir jo reikšmè dideja mažejjant skaičiui porų, gautu maišant mišinio komponentus su PAM. Sumažinus porų, gautų maišant mišinio komponentus su PAM, nuo 75 iki 25\%, putų-duju silikat- 
betonio mases plastiškasis stipris padideja nuo 1,16 $\cdot 10^{-3}$ iki $2,2 \cdot 10^{-3} \mathrm{~N} / \mathrm{mm}^{2}$, t.y. 1,9 karto.

5. Putų-duju silikatbetonio mišinio aukščiausia temperatūra yra tarpinés padèties tarp duju silikatbetonio ir putų silikatbetonio $\left(88^{\circ} \mathrm{C}\right.$ ir $\left.60^{\circ} \mathrm{C}\right)$.

6. Putu-dujų silikatbetonio bandiniu stipris gniuždant taip pat užima tarpinę padètị tarp dujų silikatbetonio bandinių ir putų silikatbetonio bandinių. Tačiau didejjant kiekiui porų, gautų maišant mišinio komponentus su PAM, jo bandinių stipris gniuždant didejja. Daugèjant porų, gautų maišant mišinio komponentus su PAM, nuo 25 iki 75\%, putu-duju silikatbetonio bandinių stipris gniuždant padideja nuo 0,9 iki $1,1 \mathrm{MPa}$, t.y. $22,22 \%$. Tai galima paaiškinti taisyklingesnemis, tolygiau pasiskirsčiusiomis poromis.

\section{Literatūra}

1. LST 1469-1997. Akytieji betonai. Bendrieji techniniai reikalavimai, $17 \mathrm{p}$.

2. А.Е. Биховскис. Исследование технологических факторов формирования теплофизических свойств газосиликата для индустриального термоизолирования труб бесканальных тепловых сетей: Автореф. дис.... канд. техн. наук. Каунас: КПИ, 1967. $22 \mathrm{c}$.

3. А.А. Лаукайтис. Исследование технологии изготовления и свойств звукопоглощающих плит "силакпор" на цементно-песчаном и известково-цементно-песчаном вяжушем: Автореф. дис.... канд. техн. наук. Каунас: КПИ, 1975. 22 с.

4. М.-Г.С. Казлаускене. Разработка технологии производства и изучение свойств звукопоглощаюших плит “силакпор" из известковопесчаной смеси: Автореф. ... дис. канд. техн. наук. Москва, 1978. 22 с.

5. А.Е. Биховскис, М.-Г.С. Казлаускене, Е.И. Янкунайте. О возможности регулирования физико-механических свойств ячеистого бетона низкой плотности // Сб. трудов ВНИИтеплоизоляция, Вильнюс, 1986, с. 47-54.

6. А.В. Дудик, А.И. Ожалене, Е.П. Карлашева. Влияние некоторых органических добавок на физико-механические свойства ячеистого бетона // Сб. трудов ВНИИТеплоизоляция, Вильнюс, 1986 , c. $55-61$

7. A. Laukaitis. Akytbetonis su anglies plaušu // Termoizoliacijos instituto darbų rinkinys, 1994, p. 3-9.

8. A. Laukaitis. Technologinių veiksniu įtaka duju betono savybėms // Cheminé technologija, 1995, Nr. 2, p. 21-24.

9. A. Laukaitis. Dujų betono su mišria rišančiaja medžiaga formavimo ypatumų tyrimai // Statyba, Nr.4 (4), Vilnius: Technika, 1995, p. 75-81.

10. A. Laukaitis. Akytojo betono sudečiu skaičiavimas ir jo savybių tyrimy metodikos. Vilnius: Termoizoliacija, 1996,24 p.
11. А. Лаукайтис, А. Дудик. Исследование гидрофобизации газосиликата плотностью $300-450 \mathrm{kr} / \mathrm{M}^{3}$ // Statyba, Nr. 3(7), Vilnius: Technika, 1996, p. 33-40.

12. A. Laukaitis, L.J. Kunskaitè. Mažo tankio akytojo betono oro laidumo tyrimai // Statyba, Nr. 3(7), Vilnius: Technika, 1996, p. 41-45.

13. A. Laukaitis, V. Lasauskas. Akytojo betono garso absorbcijos tyrimai // Statyba, Nr. 4(8), Vilnius: Technika, 1996, p. 67-72.

14. A. Laukaitis. Influence of Porous Concrete Waste on Porous Concrete Properties // Medžiagotyra, 1996, Nr. 2 , p. $46-49$.

15. A. Laukaitis. Vandens temperatūros j̣taka duju silikatbetonio masès išilimui ir pūtimuisi // Cheminè technologija, 1997, Nr. 1(5), p. 46-50.

16. A. Laukaitis. Ekvivalentinio rišamosios medžiagos kiekio nustatymas gaminant akytuosius betonus // Lietuvos mokslas ir pramone. Silikatu technologija: Konferencijos pranešimy medžiaga. Kaunas: Technologija, 1997, p. 5588.

17. A. Laukaitis. Technologinių veiksnių ịtaka putụ cementbetonio formavimo mišiniu ir gaminių savybems // Statyba, Nr. 3(11), Vilnius: Technika, 1997, p. 52-56.

18. А.П. Меркин. Ячеистые бетоны. Научные и практические предпосылки дальнейшего развития // Строительные материалы, 1995, № 2, c. $11-15$.

19. G. Kühne. Herstellung und Anwendung sehrleichter Gasbetone in der DDR. VII Konferencia o porobetone so zahraničnou ucastou, Bratislava, ČSSR, 1985, p. 127130 .

20. В.В. Михайловский, Н.Н. Скубаренко. Применение анионактивных ПАВ при производстве бетона // Материалы четвертой конференции по ячеистым бетонам. Саратов-Пенза, 1969, с. 2631.

21. А.П. Меркин, Р.А. Гаджиты. Исследования по интенсификации процессов производства и улучшению физико-технических свойств ячеистых бетонов методом газопенной поризации // Материалы четвертой конференции по ячеистым бетонам. Саратов-Пенза, 1969, с. 41-44.

22. Н.И. Федынин, С.И. Меркулова. Получение быстротвердеюшего неавтоклавного золобетона пониженной объемной массы // Строительные материалы. 1979, № 1, с. 16-18.

\section{Iteikta 19970703}

\section{THE INFLUENCE OF TECHNOLOGICAL FACTORS ON FOAM-GASEOUS SILICATE FORMATION MIXTURES AND PRODUCT PROPERTIES}

\section{A. Laukaitis}

Sum m a r y

The aim of this work was to investigate $300 \mathrm{~kg} / \mathrm{m}^{3}$ density foam-gaseous silicate concrete production parameters and properties. The optimal mentioned density product formation parameter determination was conducted in a wide density interval. 
The raw material chemical composition is given in Table 1. Sand slime and porous silicate concrete mixture formation was performed in a laboratory mixer at $750 \mathrm{RPM}$.

Surface active agents sulphanol and OP-10 (ethylphenyl ethylene glycol ether) was used for this purpose. An additional blowing agent-aluminium powder hydrophilizated with sulfanol $(20 \mathrm{~g} / \mathrm{kg})$ was used. Formation mixture plasticity strength was calculated according to equation 1 .

Low-density porous silicate concrete sample compression strength depends not only on raw material fineness, binder amount, but also on its structure. Cast silicate concrete samples (without aluminium powder) were formed to determine the milled sand fineness needed for the optimal mixture activity. Their compression strength at $1100 \mathrm{~kg} / \mathrm{m}^{3}$ density was calculated using equation 2 . The sample compression strength dependency on mixture activity and sand fineness is given in Fig 1 . The cast silicate concrete mixture technological parameters are given in Table 2 . The mixtures activity is $20 \%$, when the sand fineness approaches $130 \mathrm{~m}^{2} / \mathrm{kg}$ and $27 \%-340,31 \%$ - 500. Surface active materials amount $(0,1-0,2 \%)$ lowers the silicate concrete samples compression strength insignificantly (Fig 2).

The formation mixture envolves the surrounding air during sand slime and surface active agent mixing and partly swells. The amount of entrained air depends on the mixing time (Fig 3). However the main result is reached in 5 min. The slime density decreases from 1.7 to $0.8 \mathrm{~kg} / \mathrm{l}$, ie by 2.1 times. The mixing of surface active materials with all the mixture components is more effective, then whipping the slime separately with surface active agent and then adding lime and mixing again with the blown sand slime (Fig 4). This is explained by the fact, that when lime is added to the blown sand slime, its structure is partly destroyed.

The surface active additives lower the foam silicate concrete formation mixture fluidity (Fig 5), due to the absorbed air during mixing. Sulphanol is a more effective surface active agent, than OP - 10 (Fig 5).
It is impossible to reach a sample density lower than $400 \mathrm{~kg} / \mathrm{m}^{3}$, when surface active agents are mixed with silicate concrete mixture.

That is why experiments were conducted where aluminium powder was added, ie a foam-gaseous silicate concrete was produced. Its density depends an V/S ratio and aluminium powder amount (Fig 6).

The investigation of $300 \mathrm{~kg} / \mathrm{m}^{3}$ density porous silicate concrete mass plasticity strength showed that it is the highest for gaseous silicate concrete and the lowest for foam silicate concrete. Foam-gaseous silicate concrete mass plasticity strength occupies an intermediate position (Fig 7) The porous silicate concrete mixtures highest temperature also depends on the porous silicate type. A gaseous silicate concrete mixture reaches $88{ }^{\circ} \mathrm{C}$ already in $30 \mathrm{~min}$. Foam silicate concrete temperature increases more slowly and reaches $60^{\circ} \mathrm{C}$ in $60 \mathrm{~min}$. Foam-gaseous silicate concrete mixture temperature occupies an intermediate position and reaches $69^{\circ} \mathrm{C}$ after $36 \mathrm{~min}$ (Fig 8 )

The sample compression strength is the highest for foam silicate concrete and the lowest for gaseous silicate concrete. Foam-gaseous silicate concrete sample compression strength occupies an intermediate position and depends directly on pores produced by whipping sand slime with surface active materials and mixture mixing with $\mathrm{Al}$ powder, ratio (Fig 9).

This is predetermined by the different pore origin and pore structure formed during different degrees of mass warm-up. The latter was discussed in our earlier publications $[8,13,15]$

Antanas LAUKAITIS. Doctor (technical sciences). Director of Institute Termoizoliacija. Institute Termoizoliacija, Linkmeny̨ 28, 2600 Vilnius, Lithuania.

A graduate of Kaunas Polytechnic Institute, 1967 (industrial engineer). Doctor, 1975. Author of 76 papers, 16 inventions and 4 patents. Research interests: thermal insulation and acoustical products made of porous concrete and their technology, heat insulating and acoustical materials 